\title{
The Higher Education Sustainability before and during the COVID-19 Pandemic: A Spanish and Ecuadorian Case
}

\author{
Johanna Andrea Navarro-Espinosa ${ }^{1}$, Manuel Vaquero-Abellán ${ }^{2,3, * \mathbb{C}}$, Alberto-Jesús Perea-Moreno ${ }^{4} \mathbb{(}$, \\ Gerardo Pedrós-Pérez ${ }^{4}$, Pilar Aparicio-Martínez ${ }^{2,3, *(\mathbb{D})}$ and $\mathbf{M}^{\mathrm{a}}$ Pilar Martínez-Jiménez ${ }^{4,5}$ (D) \\ 1 Unidad de Seguimiento a Graduados, Banca Laboral y Prácticas Pre Profesionales, Universidad de ECOTEC, \\ Guayaquil 090501, Ecuador; jnavarro@ecotec.edu.ec \\ 2 GC12 Clinical and Epidemiological Research in Primary Care, Campus de Menéndez Pidal, \\ Instituto Maimónides, Universidad de Córdoba, 14071 Córdoba, Spain \\ 3 Departamento de Enfermería, Fisioterapia y Farmacología, Campus de Menéndez Pidal, \\ Universidad de Córdoba, 14071 Córdoba, Spain \\ 4 Departamento de Física Aplicada, Radiología y Medicina Física, Edificio Albert Einstein, \\ Campus de Rabanales, Universidad de Córdoba, 14071 Córdoba, Spain; aperea@uco.es (A.-J.P.-M.); \\ fa1pepeg@uco.es (G.P.-P.); fa1majip@uco.es (M.P.M.-J.) \\ 5 Responsable Grupo Investigación PAIDI de la Junta de Andalucía TEP149, Modelos de Simulación en \\ Energías, Transporte, Física, Ingeniería y Riesgos Laborales, Edificio Albert Einstein, Campus de Rabanales, \\ Universidad de Córdoba, 14071 Córdoba, Spain \\ check for \\ updates \\ * Correspondence: en1vaabm@uco.es (M.V.-A.); n32apmap@uco.es (P.A.-M.); Tel.: +34-620096799 (M.V.-A.); \\ +34-679727823 (P.A.-M.)
}

Citation: Navarro-Espinosa, J.A.; Vaquero-Abellán, M.; Perea-Moreno, A.-J.; Pedrós-Pérez, G.; Aparicio-Martínez, P.; Martínez-Jiménez, M.P. The Higher Education Sustainability before and during the COVID-19 Pandemic: A Spanish and Ecuadorian Case. Sustainability 2021, 13, 6363. https:/ / doi.org/10.3390/su13116363

Academic Editors: José Antonio

Marín-Marín, Santiago Alonso-García and Fernando José Sadio Ramos

Received: 11 May 2021

Accepted: 1 June 2021

Published: 3 June 2021

Publisher's Note: MDPI stays neutral with regard to jurisdictional claims in published maps and institutional affiliations.

Copyright: (c) 2021 by the authors. Licensee MDPI, Basel, Switzerland. This article is an open access article distributed under the terms and conditions of the Creative Commons Attribution (CC BY) license (https:// creativecommons.org/licenses/by/ $4.0 /)$.
Abstract: Information and communication technologies (ICTs) are key to create sustainable higher education institutions (HEIs). Most researchers focused on the students' perspective, especially during the online teaching caused by COVID-19; however, university teachers are often forgotten, having their opinion missing. This study's objective was to determine the factors that contribute to the inclusion of ICTs. The research based on a comparative study through an online qualitative survey focused on the inclusion and use of ICTs in two HEIs and two different moments (pre- and post-lockdowns). There were differences regarding country and working experience $(p<0.001)$, being linked to the ICTs use, evaluation of obstacles, and the role given to ICTs $(p<0.05)$. The COVID-19 caused modifications of the teachers' perspectives, including an improvement of the opinion of older teachers regarding the essentialness of ICTs in the teaching process $(p<0.001)$ and worsening their perception about their ICTs skill $(p<0.05)$. Additionally, an initial model focused only on the university teachers and their use of ICTs has been proposed. In conclusion, the less experienced university teachers used more ICTs, identified more greatly the problematic factors, and considered more important the ICTs, with the perception of all teachers modified by COVID-19.

Keywords: education; ICTs; university teachers; sustainability; e-learning; pre- and post-lockdowns

\section{Introduction}

Information and communication technologies (ICTs) have taken more than thirtyyears [1] to be included and integrated into the daily life of individuals [2]. These technologies have achieved unprecedented inclusion and utilization, spreading to all fields in society [3-5]. The mass production and availability of ICTs have provoked modifications in social structures, from people's social networking to the educational systems $[3,6]$. The educational field has experienced a significant variation with the inclusion of ICTs, applying a wide range of tools, from drones, for the explanation of theoretical ideas [7,8], to virtual learning environments and virtual realities [9-12]. These tools and multidisciplinary structures have given more flexibility, adaptability, and dynamics to the education system $[4,13,14]$. The educational structures tend to include ICTs with a higher compliance capacity, accessibility, and end-user attractiveness. Additionally, the utilization of virtual 
realities via mobile devices and headsets is increasing, as they allow the immersion and acquiring of theoretical or practical skills [15-17].

However, all these technologies force the teachers of any educational level to knowhow they are used, and of their benefits and shortcomings. Therefore, the teachers must adapt their profile, training, and abilities to fully integrate and utilize the ICTs in their teaching process and with the students [18-21]. It seems that the majority of authors have focused on elementary or middle educational levels, where the teachers needed to have technological and pedagogical abilities [22-24]. Nevertheless, these skills do not have to be presented among the university teachers, from lectures to professors $[18,25,26]$. According to García, although the inclusion of ICTs in higher educational levels, i.e., postgraduate studies, as educational innovation is a reality, this integration jeopardizes the quality of education when the university teachers have not received training about the ICTs and the teaching process [20]. In mid-2020, the pandemic of COVID-19 forced the higher institutions (HEIs) to include several ICTs and to move to online teaching, trying to guarantee the continuity and quality in their teaching process $[27,28]$. This shift to an online learning experience, also known as e-learning, caused the inclusion of different technologies, such as Zoom, Cisco, or Blackboard Collaborate, despite the teachers' skills and capacity to use them $[10,29,30]$. These modifications along the academic course and, of course, between countries or even regions can delimit the students' learning process [31]. Additionally, teachers have been forced to transform their teaching materials to an online format with little or no training or minimal prior practice $[27,29]$. Most teachers from HEIs were far from being prepared for the shift to a virtual teaching-learning environment $[27,29,32]$. These constant adjustments regarding virtual teaching have been complex, as there was no standard paradigm and the tools were changing as time passed $[10,30]$.

\section{Theoretical Background}

\subsection{Sustainability, Education, and ICTs}

Education plays a significant role in sustainability since it is the primary means to teach future generations, known as education for sustainability [33]. The education for sustainability focused on providing abilities and capacities for the citizens, so longterm sustained societies are possible [34]. This concept, created 30 years ago, focused on providing future inhabitants with knowledge and skills, so people are active agents in society's continuity and balance [35-37]. Moreover, quality education is essential for sustainable development in all levels of society since through it, the transformation of society is possible [36,38]. It is vital to reorientate education to develop knowledge, skills, values, and conduct to develop a sustainable society. These students will be significant agents to create and resolve the current challenges that the world faces, such as climate change, hunger, and social inequalities [33,39].

In this sense, the rapid growth of technological innovations has been welcomed as an unprecedented opportunity to address these social issues [40-42]. Teaching students in sustainable development requires that the teachers and systems are adapted to students needs, teaching level, and modifications inside the society [37,43]. The younger generations are active users of social media, technologies, and mobile apps [40,44], implying that the systems and teachers need to include these technologies to appeal to these new generations to achieve the different skills needed in a sustainable world $[45,46]$. Several authors and the United Nations Educational, Scientific and Cultural Organization (UNESCO) have stated that sustainability needs to create interactive physical or virtual environments to promote quality education $[33,38,39,43,47]$.

Moreover, UNESCO promotes ICTs as an asset to achieve Sustainable goals in different countries and emphasizes the South Hemisphere [39]. Despite the differences between developed and developing countries regarding incomes, the educational systems rely on the European countries' same structures [48-50]. An example would be Spain and other South American countries, like Ecuador, based on the same structures, laws, and principles cemented in the first legislation and created universities. Therefore, using or utilizing ICTs 
could not be significantly different from Institutions with similar roots [48-50]. Because the ICTs have a crucial role in education from a sustainable perspective, most countries have integrated them into educational environments [33]. All these measurements also focused on creating sustainable institutions or green universities, with the idea of implementing and creating sustainable policies [51,52].

However, environmental education is constantly changing because of social, political, or cultural modifications $[47,53]$. One significant change in the year 2020 was the pandemic of COVID-19, which spread throughout the world and obliged the governments to suspend all non-essential work, including teaching $[10,29]$. Especially at that moment, for the education system, there was a need to train the teachers in all levels to include the ICTs and virtual education [21]. Such interactive technologies promote students' active learning, allowing their growth and independence training, and further creating networks and collaborations, among others, to solve problems [6]. Due to the relevance of their role, most studies focused on the technologies and forgot about the teachers, especially in HEIs [31,54], whose role is to create the learning and teaching environment. Nevertheless, there are still missing data about university teachers' perspectives and most ICTs or their skills to create a sustainable educational system and achieve a sustainable environment $[22,23,36]$. Therefore, in order to fully integrate the ICTs in the educational system for sustainability [53], it is necessary to understand the current difficulties better, the participants and willingness of the active agents, i.e., teachers, and the role of COVID-19, as an outside factor that obliged the integration $[27,55]$.

\subsection{Education, ICTs, and COVID-19}

The pandemic of COVID-19 obliged countries worldwide to suspend face-to-face teaching, moving to online classes [33], putting at risk the achievement of the expectation for education according to the Goal Of Sustainability $[33,38,39]$.

Most countries lacked resources for teachers and technological tools [56], which created difficulties for the continuation of education, its quality, and the creation of a sustainable environment $[27,55]$. These differences between countries were present in different continents, such as Latin America or Europe $[57,58]$. The report from UNESCO about education in Latin America indicated that among the countries with more resources and the possibility of live classes through online distance learning modalities were Bahamas, Costa Rica, Ecuador, and Panama. However, the government did not provide technological devices. Additionally, other Latin countries provided technical training to the teachers or further support [57,59]. For instance, the Ministry of Education of Ecuador launched a self-learning course for teachers called My Online Classroom [60]. This same Ministry created and implemented the "Plan of COVID-19"; through this plan, the government wanted to guarantee the educational service during the phases and scenarios of health emergency; support the educational community in prevention; and provide protection and emotional support to teachers, parents, and students [58].

In Europe, the European Union put a united front to change to online teaching [61]; however, there was a lack of digital resources described as essential and widely used by the different governments to cope with this switch [62]. The different organizations around Europe have created and made available courses for training the teachers. Nevertheless, each country has put online teaching differently, including different distance learning modalities and resources for the teachers [63]. In the case of Spain, different reports have indicated that COVID-19 has increased the inequalities of equipment and preparation that exist between families, centers, and teachers. Moreover, Spain is an example of relegating the educational policies to focus on health measures; this country presents much more disparity because of diversity between territories [64]. Meanwhile, Spanish researchers have highlighted how the use of ICTs has negatively impacted teachers' health and how the students considered that the university teachers were capable and could change from face-to-face to online education $[65,66]$. Although few studies and reports have focused on 
the university level $[28,67,68]$, the implementation of online teaching was carried out in some scenarios without training, resources, or skills, implying longer hours of working [69].

Despite the possible differences between countries or regions, Feyen indicated that the issue with COVID-19 was the pressure that the teachers at all levels may feel stress or experience some emotional distress. This stress was based on the estimation that the working hours per week with ICTs increased $20 \mathrm{~h}$, being higher depending on the type of contract, working experience, age, or the country [69]. Nevertheless, these factors or comparisons between countries with similar structures or roots, such as Ecuador and Spain, with comparable ICTs and teachers' skills, have not been studied (Table 1) [49,70,71].

Table 1. Differences between Spain and Ecuador.

\begin{tabular}{ccc}
\hline Differences & Ecuador & Spain \\
\hline Incomes & $\begin{array}{c}\text { Low-medium incomes } \\
(108.4 \text { million in 2018) }\end{array}$ & $\begin{array}{c}\text { High incomes } \\
\text { (1.419 billons in 2018) }\end{array}$ \\
$\begin{array}{c}\text { Higher Education Law of 2010 } \\
\text { to improve education and } \\
\text { research }\end{array}$ & $\begin{array}{c}\text { Organic Law 6/2001, from } \\
\text { December 21 }\end{array}$ \\
$\begin{array}{c}\text { Number of public/private } \\
\text { institutions }\end{array}$ & 33 public/26 privates & 50 public/32 privates \\
\hline
\end{tabular}

Following the comparison between these two countries, fewer studies are available for understanding the Ecuadorian education changes caused by COVID-19 [60,72,73]. In Ecuador, recent researches have focused on the mental health of Ecuadorian students focusing on the pressure and impact of using ICTs [72], resources available at the time [60], and the experience of the teacher [72]. In Spain publications, researchers have focused on students' perspectives regarding the change to the education, use of the ICTs, and only little has included the teachers' point of view $[28,65,67,72,74]$. One Spanish research had as participants the university teachers training the future teachers from elementary schools, although the objective was to evaluate the impact of ICTs on the teaching process [75].

Moreover, few studies have been based on intercontinental analysis [76-78], with only two publications studying Ecuador and Spain [77,78]. Said-Hung et al. [76], in an Ibero-America study with a sample of 700 participants from six countries, including Spain, indicated that the perception of the teachers and students depended on individual variables, such as previous experience in virtual environments or the average number of daily hours devoted to the activities, and using ICTs. Meanwhile, Tejedor et al., analyzed the perspective of 376 students from Spain, Ecuador, and Italy regarding ICTS and HEIs, and whose results indicated the need to improve the teacher's digital skills or sources for learning [77]. Another study from this same research group studied the perspective of 196 university teachers from the same three countries, indicating the lack of information, training for the new scenario, or the limited skill of technical aspects [78].

These studies pointed out how the students identified the issues regarding their educational systems and difficulties to include ICTs, therefore, to create sustainable HEIs $[37,53,55,77]$. However, few studies included the teachers' perspective, skills, or experience, which are major factors in providing quality education and training future generations in sustainability $[50,78,79]$.

\subsection{Hypothesis and Objectives}

Because of COVID-19 and the need to continue with education, as students are the focus, teachers must have the capacity to use different ICTs and adequate resources accordingly to their needs [62]. Nevertheless, these functions and capacities are based on the teachers' training. However, as previously stated, most studies focused on students perspectives, more commonly in secondary educational levels. Only in few cases have inter-continental studies included university teachers' perception of the challenge of virtual teaching imposed by COVID-19 pandemic $[67,72,77,78,80]$. Although other researchers 
have indicated their relevance in using ICTs in education and the impact during the pandemic $[69,72]$, there is still missing information. In fact, many researchers do not focus on the working experience (which was already studied as a relevant factor [79]), differences between countries [78], and availability of ICTs, and much less on these agents' perspectives $[22,81]$.

Based on the current literature, this study's objective was to carry out a comparative study focusing on the inclusion and use of ICTs in HEIs in two different countries to determine factors (i.e., working experience or availability of resources) and in two different moments at the end and beginning of the semesters. Nevertheless, an unexpected event occurred during this research, which was the global pandemic, implying the need to include another factor, COVID-19.

Furthermore, two hypotheses were established from the previous literature:

Hypothesis H1. There is an association between ICTs use, skills, the obstacle for integration, and the country.

Hypothesis H2. There is an association between working experience and the use of ICTs, skills, and importance given to the ICTs.

\section{Materials and Methods}

\subsection{Survey Data Collection}

The present research studied the university teachers' perspective regarding the ICTs skills, the relevance of the ICTs, frequency of using ICTs to create a sustainable system, the impediments that make the inclusion of ICTs difficult, and the impact of COVID-19. Two descriptive, exploratory, and cross-sectional studies applied to comparative analysis between Spain and Ecuador were carried using a reference population of university teachers in two different set times. The set times were selected based on the final and beginning of the semester; the first survey was distributed in December 2019 and opened until January 2020, previous to the pandemic. The second time the survey was distributed between September and opened until October in 2021, after the first lockdown and quarantine of the countries.

An incidental non-probabilistic sampling, widely used in research because of the simplistic implementation [66], was used for this research. First, the selection of the universities was based on accessibility, availability in both time sets, and relevance according to the position in the international ranking for Universities. Eight universities were selected (two from the top including Polytechnic of Valencia, two from the middle including the University of Seville, and two in the bottom, including Cordoba and Ecuador since both are more recently created) [82].

The Spanish university teachers invited to participate were from the Engineering School, and the Ecuadorian teachers were from the Communication and Engineering School. The selection of this sample was based on previous studies that indicated how teachers from a more technological background seem to have more ICTs skills $[12,83,84]$ and how the Ecuadorian teachers' ratio seems to be higher than Spanish [85]. The university teachers were contacted through email, by which the information (like objectives and type of study) was explained, and they were asked for their willingness to participate. After receiving positive feedback, the willing participants received the link to the survey. They were encouraged to spread the survey among other colleagues from the same area and center, obtaining an anonymous and random sample. Based on previous intercontinental studies [78] and an estimated five percent response rate [86], the sample calculation was carried out. Based on the sample of university teachers from the institutions selected and accepting an alpha risk of 0.05 and a beta risk of 0.2 in a bilateral contrast, 43 subjects are required in the first group and 43 in the second to detect as statistically significant the difference between two proportions, which for group 1 is expected to be 0.36 and group 2 of 0.66 (or vice versa group 10.66 and group 20.33 ). 
The total sample was teachers from three Spanish (Cordoba, Seville, and Valencia) and one Ecuadorian HEIs, with a higher rate of response among Ecuadorian teachers (as the median the number of fully responded in the survey was set at 24) than Spanish (as the median the number of responses was set at 20). The number of university teachers that responded to the survey for the first time was 51, increasing to 55 university teachers after the lockdowns. Only 44 university teachers responded fully to the survey before the pandemic and after the lockdowns, being identified through the computer's IP, which was later codified following the ethical and privacy codes [87]. This study was conducted using a questionnaire completed online, which was the optimal methodological mechanism to collect information.

\subsection{Instruments}

This study was implemented using a questionnaire transformed into online surveys distributed through QuestionPro (Survey Analytics LLC, San Francisco, CA, USA). The survey was formed by 11 items, selecting one answer, and based on the Likert scale from 0 (total disagreement) to 5 (Total agreement) (Table A1). The survey was structured in four segments: the information sheet, the objective, ethical code, confidentiality, and anonymization. After accepting to participate, the volunteers accessed the central section, leaving some items unmarked or dropping out at any moment. The main section was the teachers' opinion about ICTs and their inclusion in the education field in higher education, from which the data was obtained. The items were country, working experience, ICTs skills, frequency of using more ICTs for different educational purposes, the evaluation of obstacles, the evaluation of the ICTs role in the learning process, the relevance is given to ICTs as an essential key for the educational structure and how no clear evidence of educational changes is an obstacle for integrating ICTs. The validity, reliability, and consistency were studied for the survey. The validity was calculated through Pearson's correlation, indicating that all items were valid $(p<0.001)$, except for the availability of software and the internet $(p>0.05)$. The reliability statistics were applied to the survey items, showing really good reliability of the test to measure the workers' perception (Cronbach's Alpha $=0.81$; Corrected item > 0.4; ANOVA Cochran's $Q=178.13, p<0.001)$. Moreover, the Hedges' $\mathrm{g}$ was used to determine the size effect of the samples regarding the working experience (0.23), essentialness of ICTs (0.19), the availability of resources (0.33), lack of resources (0.41), ICTs skills (0.84), and the role of ICTs in the teaching process (0.89).

The participants received an email in which they were informed about the survey's objectives, the time allowed to complete it $(10 \mathrm{~min})$, the voluntary nature, and the possibility of not completing it. This survey also included a section where the participants had to give their consent before completing it. The exclusion criteria were teachers from different educational levels. The data was organized using the identification given to the participants based on their IP direction.

The programs used were Excel version 2017 (Microsoft Corporation, Redmond, WA, USA) and SPSS program version 25 (IBM SPSS Statistics) for the statistical analysis. All data were saved in a cloud available only to the researchers.

\subsection{Procedure}

Teachers approved a participant information statement, consent form and accessed questionnaires through the online version. The information statement included the study's objective, the explanation of the survey, the voluntary and consent to participate, and anonymity after agreeing to fill the survey through an option of "Yes/No," passing to the questionnaire, completing it partially or entirely, or to the acknowledgments. This informed consent followed the fundamental principles established in the Declaration of Helsinki of 1964, the World Medical Association, subsequent amendments, and the 1996 Council of Europe Convention on Human Rights and Biomedicine and the Data Protection Law 3/2018 5. Moreover, this study did not include any medical information focusing on 
the academic's opinion, though it was in line with a project on Occupational Safety that received Ethical Research Approval (Reference 4258).

\subsection{Statistical Analysis}

The survey was completed by 51 teachers in the first period, although a variable was indicated as not completed or rather not say. The second time the survey was fully completed by 55 teachers. For both samples set in different periods, the qualitative variables were studied using frequencies (absolute and relative) and the median with their $95 \%$ confidence intervals (CI). The Kolmogorov-Smirnov test and the Shapiro-Wilk test were applied, indicating that the data did not follow normality $(p<0.001)$. The chi-test, Kendall's tau-b, Cramer's V, McNemar test, and Spearmen's correlations tests were applied accordingly in both samples. The university teachers belong to different centers had diverse working experiences.

Additionally, a sample of 44 participants that fully completed the survey both times, according to id, were statistically analyzed to determine the impact of COVID-19. The median and frequencies and IC $\% 95$ were used; and the no-parametric tests for independent variables were applied to determining differences, such as chi-test and correlations. Based on two different periods (pre- and post-lockdown), the non-parametric repeated measures taken over time, specifically the mixed-model analysis of variance (ANOVA), were used to determine the modifications in ICT implementation using simultaneously country, preand post-lockdown, and experience as independent variables. Multiple linear regressions were carried out.

\section{Results}

\subsection{Results Previous the Pandemic}

The initial analyses of the university teachers' perspective before the pandemic in Spain and Ecuador were analyzed to determine differences inside the sample (Table 2). The analysis showed significant variances between the Spanish and Ecuadorian samples for teaching at different levels $\left(X^{2}=5.76 ; p=0.02\right)$ and the working experience $(p<0.05)$. The availability of ICTs (computers, software, virtual environments, and the internet) and skills did not show significance between both countries (Table 2). Additionally, the perception of the essentialness of ICTs in the teaching process was significantly different among countries $\left(X^{2}=6.52 ; p=0.04\right)$.

Table 2. Descriptive of the variables accordingly to the country.

\begin{tabular}{|c|c|c|c|c|}
\hline \multirow[b]{2}{*}{ Factors } & & \multicolumn{3}{|c|}{ Before the Pandemic $(\mathrm{N}=51)$} \\
\hline & & $\begin{array}{l}\text { Spain } \\
(41.2 \%)\end{array}$ & $\begin{array}{c}\text { Ecuador } \\
(58.8 \%)\end{array}$ & $p$-Value \\
\hline \multirow{2}{*}{ Teaching at different levels } & Undergraduate & $61.9 \%$ & $90.0 \%$ & \multirow{2}{*}{0.016} \\
\hline & Postgraduate & $38.1 \%$ & $10.0 \%$ & \\
\hline \multirow{4}{*}{ Working experience } & Less than ten years & $23.8 \%$ & $53.3 \%$ & \multirow{4}{*}{$<0.006$} \\
\hline & Between 10 to 20 & $19.0 \%$ & $23.3 \%$ & \\
\hline & Between 20 to 30 & $23.8 \%$ & $16.7 \%$ & \\
\hline & More than 30 & $33.3 \%$ & $6.7 \%$ & \\
\hline \multirow{5}{*}{ Availability of ICTs } & Rather not say & $1.2 \%$ & $5.9 \%$ & \multirow{5}{*}{0.12} \\
\hline & Nothing & $10.7 \%$ & $10.9 \%$ & \\
\hline & Little & $10.7 \%$ & $20.0 \%$ & \\
\hline & Enough & $29.8 \%$ & $21.7 \%$ & \\
\hline & A lot & $47.6 \%$ & $41.7 \%$ & \\
\hline \multirow{4}{*}{ ICTs skills } & Little & $0 \%$ & $0 \%$ & \multirow{4}{*}{0.59} \\
\hline & Enough & $14.3 \%$ & $6.7 \%$ & \\
\hline & Many & $52.4 \%$ & $63.3 \%$ & \\
\hline & Outstanding & $33.3 \%$ & $30.0 \%$ & \\
\hline
\end{tabular}


The Ecuadorian participants were more likely to teach to undergraduate students $(\rho=-0.34 ; p=0.02)$ and have less working experience $(\rho=-0.39 ; p=0.003)$. These participants indicated with more frequency that the role of ICTs in education was essential $(\rho=-0.49 ; p<0.001)$.

The working experience was studied since it has a great significance and seemed to be a vital factor in its integration and use. The $66.7 \%$ of the sample had less than twenty years of working experience, being present significant differences according to the essentialness of ICTs $\left(X^{2}=15.73 ; p=0.04\right)$. The median was set in between ten and twenty years, and the working experience was studied using the median as a breakpoint. Less than twenty years of working experience, independently from the country, was associated with using more frequently the ICTs for researching $(\rho=-0.32 ; p=0.01)$ and for pedagogic purposes $(\rho=-0.36 ; p=0.009)$ (Figure 1).

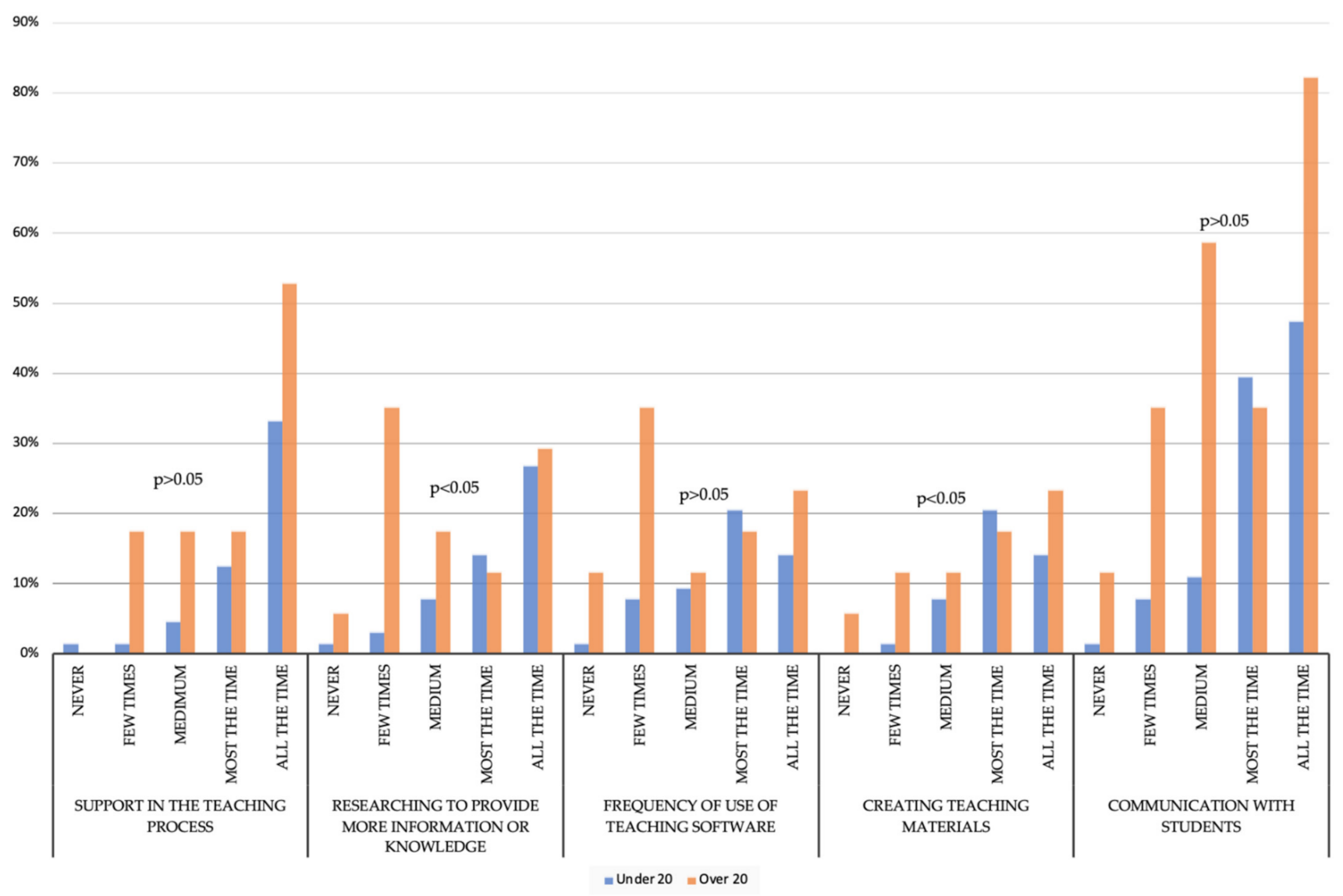

Figure 1. The opinion of university teachers about the frequency of ICTs utilization based on the breakpoint of twenty years of working experience.

There were also significant differences between university teachers with less than twenty years of working experience regarding their opinion of the relevant role that may have ICTs in the learning process $\left(X^{2}=6.75 ; p=0.03\right)$. In this sense, teachers with less working experience seemed to give more relevance to the role of ICTs $(\rho=-0.35 ; p=0.02)$. The factors that may impede the teaching process and the integration of the ICTs were studied according to working experience. The workers under 20 years of experience indicated that insufficient resources $(17.6 \%)$, software or educational programs $(26.5 \%)$, educational training $(32.4 \%)$, educational models $(29.4 \%)$, and time $(34.9 \%)$ were essential as obstacles. In contrast, the workers over 20 years of experience said that insufficient resources $(21.6 \%)$, software or educational programs $(27 \%)$, educational training $(26.4 \%)$, educational models $(31.6 \%)$, and time $(32.5 \%)$ were considered necessary as obstacles. 
The associations between the working experience were carried out for each obstacle, indicating associations between younger working experience and higher consideration of the obstacles, being only significant for educational models $(\rho=-0.35 ; p=0.02)$. Finally, the segmentation accordingly to working experience was studied for no clear evidence of educational changes is an obstacle for integrating ICTs, showing no significant differences $(p>0.05)$.

\subsection{Results Post-Lockdown Caused by COVID-19}

The data of the university teachers after the lockdown in both countries was analyzed (Table 3). The results indicated significant differences between countries for teaching at different levels $\left(X^{2}=4.85 ; p=0.03\right)$ and the working experience $(p=0.003)$. The availability of ICTs (computers, software, virtual environments, and the internet) and skills did not show significance between both countries (Table 3). Meanwhile, the perception of the essentialness of ICTs in the teaching process indicated significant differences $\left(X^{2}=17.87\right.$; $p<0.001)$. Moreover, the correlations highlighted how Spanish university teachers from Ecuador seemed to be more likely to have less working experience $(\rho=-0.39 ; p=0.003)$ and more frequently have considered the role of ICTs in education was essential $(\rho=0.55$; $p<0.001)$.

Table 3. Descriptive of the variables accordingly to the country.

\begin{tabular}{|c|c|c|c|c|}
\hline \multirow{2}{*}{\multicolumn{2}{|c|}{ Factors }} & \multicolumn{3}{|c|}{ Post-Lockdown $(\mathrm{N}=55)$} \\
\hline & & $\begin{array}{c}\text { Spain } \\
(32.7 \%)\end{array}$ & $\begin{array}{c}\text { Ecuador } \\
(67.3 \%)\end{array}$ & $p$-Value \\
\hline \multirow{2}{*}{ Teaching at different levels } & Undergraduate & $66.7 \%$ & $67.6 \%$ & \multirow{2}{*}{0.03} \\
\hline & Postgraduate & $33.3 \%$ & $24.3 \%$ & \\
\hline \multirow{4}{*}{ Working experience } & Less than ten years & $22.2 \%$ & $40.5 \%$ & \multirow{4}{*}{$<0.001$} \\
\hline & Between 10 to 20 & $11.1 \%$ & $35.1 \%$ & \\
\hline & Between 20 to 30 & $22.2 \%$ & $18.9 \%$ & \\
\hline & More than 30 & $44.4 \%$ & $5.4 \%$ & \\
\hline \multirow{4}{*}{ Availability of ICTs } & Nothing & $11.9 \% \%$ & $6.75 \%$ & \multirow{5}{*}{0.5} \\
\hline & Little & $6.9 \%$ & $8.8 \%$ & \\
\hline & Enough & $27.9 \%$ & $16.2 \%$ & \\
\hline & A lot & $53.3 \%$ & $68.3 \%$ & \\
\hline \multirow{4}{*}{ ICTs skills } & Little & $0 \%$ & $0 \%$ & \\
\hline & Enough & $27.8 \%$ & $16.2 \%$ & \multirow{3}{*}{0.12} \\
\hline & Many & $66.7 \%$ & $54.1 \%$ & \\
\hline & Outstanding & $5.6 \%$ & $29.7 \%$ & \\
\hline
\end{tabular}

The Ecuadorian university teachers were more likely to consider a more active role of ICTs in education $(\rho=0.36 ; p=0.006)$, use more frequently the ICTs for researching $(\rho=-0.29 ; p=0.03)$ and pedagogic purposes $(\rho=0.38 ; p=0.005)$, considered that the lack of resource, software, pedagogic training, and models were vital factors of the integration of ICTs $(p<0.01)$.

The working experience was studied since it has a great significance and seemed to be a key factor in its integration and use. Workers with less experience were more likely to be from Ecuador $(\rho=-0.39 ; p=0.003)$, considered more essential role of ICTs $(\rho=-0.51$; $p<0.001)$, give a more relevant role to ICTs $(\rho=-0.37 ; p=0.01)$, considering an obstacle the lack of resources $(\rho=-0.28 ; p=0.04)$ and lacking pedagogic training $(\rho=-0.28 ; p<0.001)$.

A total of $61.8 \%$ of the sample had less than twenty years of working experience, being present significant differences according to the essentialness of ICTs $(p=0.03)$. The median was two representing the range from ten to twenty years. Less than twenty years of working experience, independently from the country, was linked to considered ICTs essential $(\rho=-0.47 ; p<0.001)$, the role given ICTs $(\rho=-0.32 ; p=0.02)$ using more frequently, the importance given to the lack of resources $(\rho=-0.35 ; p=0.009)$, pedagogic 
training $(\rho=-0.32 ; p=0.02)$ and models $(\rho=-0.32 ; p=0.02)$, as obstacles to integrating the ICTs in the education.

\subsection{Comparison Pre-and Post-Lockdown}

The number of university teachers who completed both surveys, pre- and post-lockdown, was 18 from Spain and 26 from Ecuador, teaching $66.7 \%$ of the Spanish and $88.5 \%$ of the Ecuadorian undergraduate students. There were no significant differences between the two times and between countries $(p>0.05)$. The $88.4 \%$ of Ecuadorian teachers had less than twenty years of teaching experience $(61.5 \%$ less than ten years and $26.9 \%$ between ten and twenty); meanwhile, $66.6 \%$ of Spanish usually had a minimum of 20 years $(44.4 \%$ with than 30 years) $(p<0.001)$. The working experience hardly changed from the preand post-lockdown, changing $4.5 \%$ of the university teachers. This working experience was linked to the essentialness of ICTs pre- $(\rho=-0.65 ; p<0.001)$ and post-pandemic ( $\rho=-0.39 ; p=0.003)$, being the younger teachers, the ones who considered more highly the ICTs. Additionally, the working experience was linked to the importance given to the role of ICTs in the teaching process only pre-lockdown $(\rho=-0.58 ; p<0.001)$. The working experience was associated with the frequency of using ICTs for different purposes for creating teaching materials $(\rho=-0.35 ; p=0.04)$, increasing the frequency of use of the ICTs in the IC $95 \%$ from $5.2 \%$ to $8.9 \%$ (Figure 2). In general, the frequency of always using the ICTs was 39.7\% (95\% CI 32.3-44.6\%) before the lockdown and 46.8\% (95\% CI 42.4-51.3\%) after the lockdown.

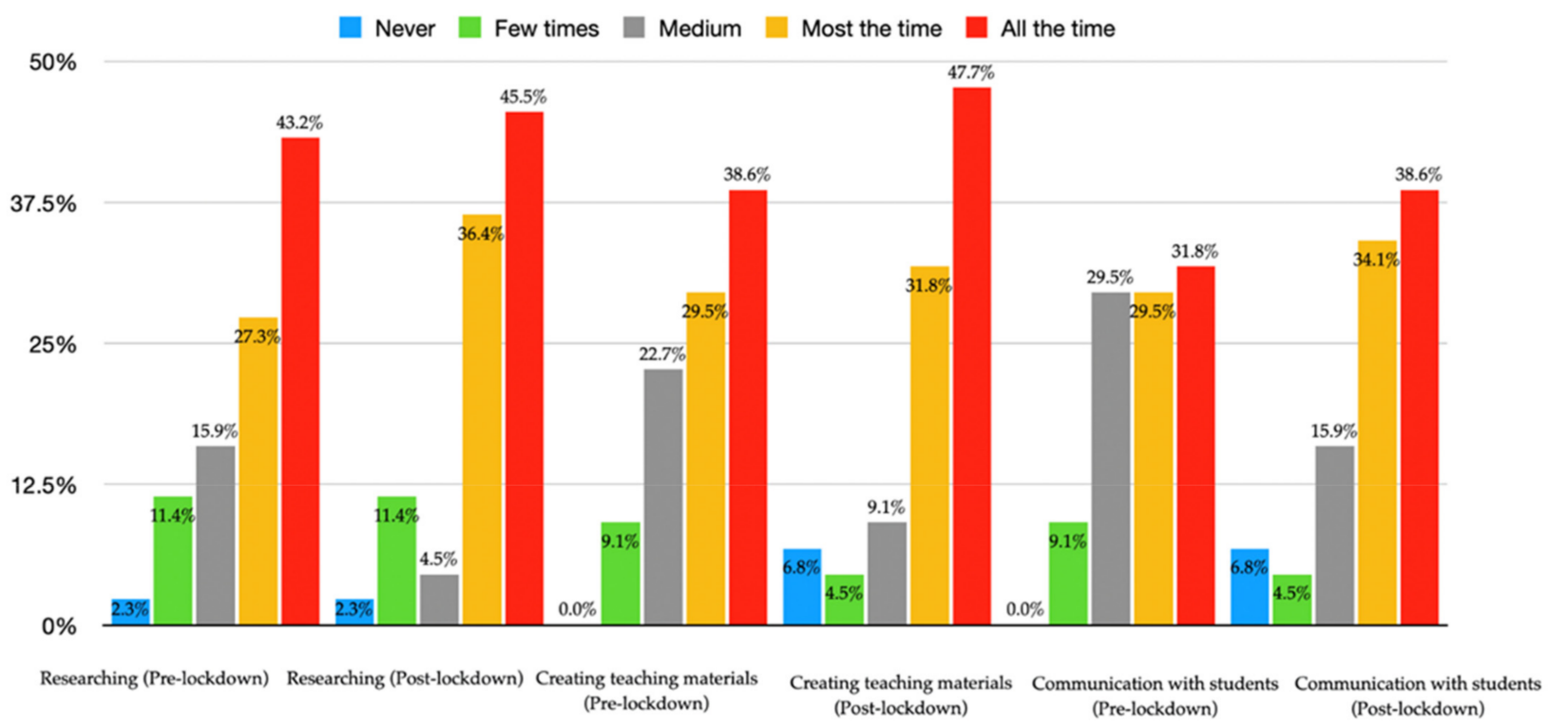

Figure 2. The opinion of university teachers about the availability of resources pre- and post-lockdown.

Since the sample was segmented mainly by having more or less than 20 years of working experience, this cut point was analyzed for the frequency of using ICTs before and after the lockdown, the availability of ICTs, ICTs skills, and perception of the obstacles. The ICTs utilization to support the teaching process through programs for designing content, researching to provide more information, creating innovative or interactive teaching materials, and communication with students indicated differences regarding the working experience and the two-time sets (Table 4). This table indicated that the university teachers with less working experience frequently used the ICTs after the first lockdown for researching to provide more information, create innovative or interactive teaching materials, and communicate with students $(p<0.05)$. Additionally, the workers with less experience indicated that the use of ICTs increased after the lockdown for researching to provide more 
information or knowledge $(\rho=-0.36 ; p=0.02)$ for creating teaching materials $(\rho=-0.43$; $p=0.007)$ and communication $(\rho=-0.54 ; p<0.001)$.

Table 4. Symmetric measures of the working experience and frequency of using the ICTs in the two-time sets.

\begin{tabular}{|c|c|c|c|c|}
\hline \multirow[b]{2}{*}{ Resources } & \multicolumn{2}{|l|}{ Pre-Lockdown } & \multicolumn{2}{|l|}{ Post-Lockdown } \\
\hline & $\begin{array}{l}\text { Under and Above } 20 \text { Years } \\
\text { of Working Experience }\end{array}$ & $p$-Value & $\begin{array}{l}\text { Under and Above } 20 \text { Years } \\
\text { of Working Experience }\end{array}$ & $p$-Value \\
\hline Support in the teaching process & -0.21 & 0.15 & -0.22 & 0.16 \\
\hline $\begin{array}{l}\text { Researching to provide more } \\
\text { information or knowledge }\end{array}$ & -0.24 & 0.82 & -0.34 & 0.02 \\
\hline Teaching software & -0.19 & 0.19 & -0.18 & 0.15 \\
\hline Creating teaching materials & -0.16 & 0.36 & -0.39 & 0.007 \\
\hline Communication or collaborative tool & -0.15 & 0.29 & -0.49 & $<0.001$ \\
\hline
\end{tabular}

Additionally, the mixed ANOVA test was calculated for the two-time sets, the working experience, and the frequency of using the different resources. The results indicated that the interaction of these variables was not significant $(p=0.13)$, but there were significant differences between the frequency of using ICTs and working experiences (mean difference $=0.74 ; p>0.001$ ), making it more significant after the lockdowns (Figure 3).

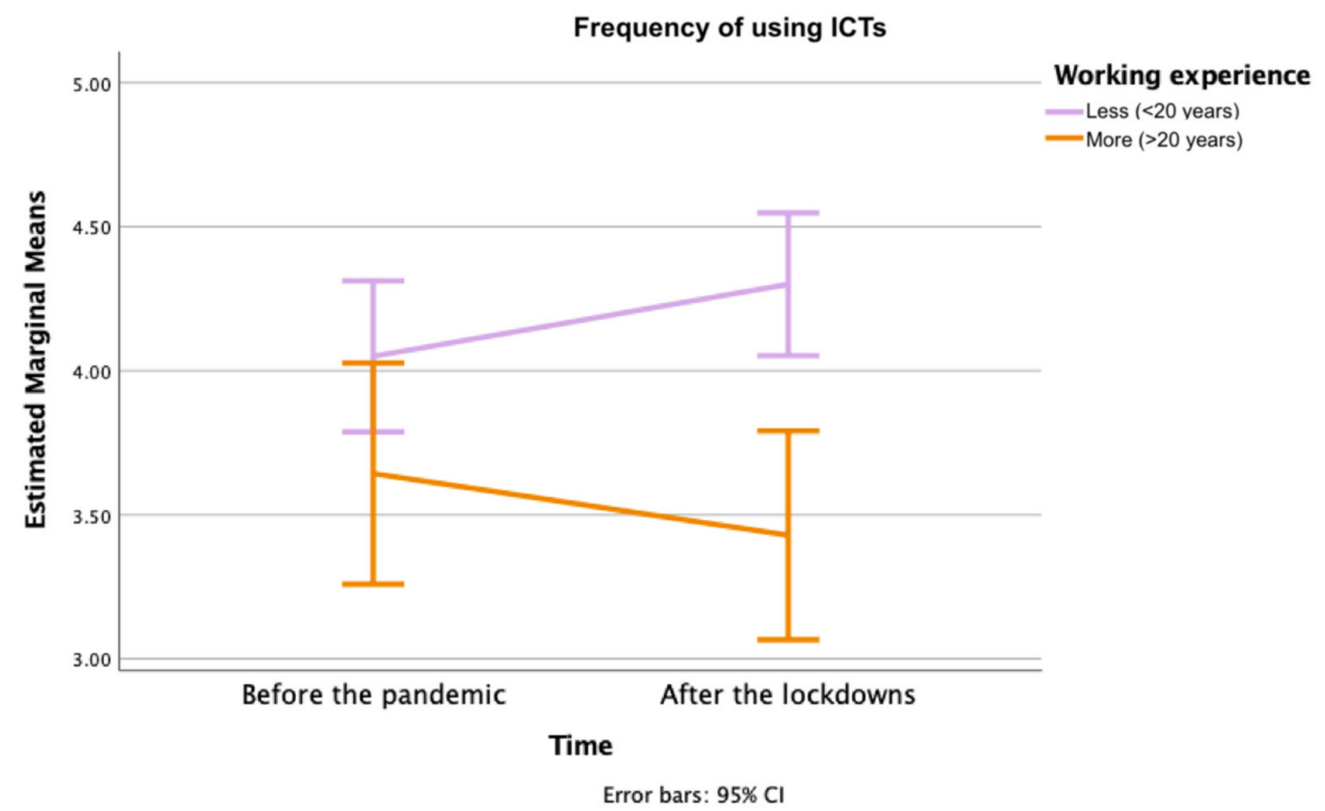

Figure 3. Frequency of using ICTs according to working experience and the two periods of time.

The working experience was also studied for ICTs' essentialness in the two-time sets. The difference between the working essentialness and two-times sets was significant $(p=0.64)$, although when analyzed the working experience, essential, and both time sets, there were significant differences (sum of squares $=1.6 ; p<0.006$ ). The essentialness of ICTs for less working experience was almost the same before and after the lockdowns. In contrast, university teachers with more working experience indicated an increase in the essentialness of the ICTs. Their perception changed from answering No $(35.7 \%$ before and $7.1 \%$ after the lockdowns) to Maybe or Yes (28.6\% before and 57.1\% after the lockdowns).

The working experience was linked to the ICTs skills, improving the perception of ICTs skills among the workers with less experience by $10 \%$ and worsening in older workers (10\% considered enough before the lockdown and 35.7\% after the lockdown). However, there were no significant differences between pre- and post-lockdown $(p>0.05)$. 
Moreover, the mixed ANOVA, using the ICTs skills related to the two-time sets (before and after the lockdown) and the working experience, was carried out. According to the univariant model, the analysis indicated significant differences within-subjects $(p=0.003)$ for the working experience and ICTs skills. However, the time with ICTs skills combined with working experience was not significant $(p=0.78)$. The correlations showed that less working experience was linked to indicating more commonly to have outstanding skills before $(\rho=-0.37 ; p=0.013)$.

The workers with less than 20 years of experience indicated that insufficient resources ( $20.0 \%$ before and $56.7 \%$ after), software or educational programs ( $20 \%$ before and $60.0 \%$ ), educational training ( $30 \%$ before and $63.3 \%$ after), educational models ( $40 \%$ before and $53.3 \%$ after), and time (36.7\% before and 50\% after) were essential as obstacles. The workers over 20 years of experience said that insufficient resources ( $21.4 \%$ before and $14.3 \%$ after), software or educational programs (21.4\% before and $7.1 \%$ after), educational training ( $21.4 \%$ before and after), educational models ( $14.3 \%$ before and after), and time (21.4\% before and after) were considered necessary as obstacles. The associations between the working experience for this segmentation were carried out for each obstacle before and after the lockdown (Table 5), indicating associations between younger working experience and higher consideration of the obstacles mainly after the lockdown (insufficient resources, educational training, educational models and time) $(p<0.05)$.

Table 5. Symmetric measures of the working experience and the factor whose lacking difficulty the teaching process in the two-time sets.

\begin{tabular}{|c|c|c|c|c|}
\hline \multirow[t]{2}{*}{ Resources } & \multicolumn{2}{|l|}{ Pre-Lockdown } & \multicolumn{2}{|l|}{ Post-Lockdown } \\
\hline & $\begin{array}{l}\text { Under and Above } 20 \text { Years } \\
\text { of Working Experience }\end{array}$ & $p$-Value & $\begin{array}{l}\text { Under and Above } 20 \text { Years } \\
\text { of Working Experience }\end{array}$ & $p$-Value \\
\hline Resources & -0.03 & 0.84 & -0.38 & 0.003 \\
\hline Software & -0.12 & 0.43 & -0.46 & $<0.001$ \\
\hline Educational training & -0.17 & 0.21 & -0.39 & 0.002 \\
\hline Educational models & -0.30 & 0.03 & -0.43 & $<0.001$ \\
\hline Time & -0.23 & 0.11 & -0.29 & 0.03 \\
\hline
\end{tabular}

The results of the ANOVA test for lacking ICTs (resources, software, educational training, models, time, and no research about the clear benefits) in both times and related to the working experience indicated no significant differences for lacking ICTs and the working experience (Table 6). The working experience and the perception of lacking ICT indicated differences between group through the univariant tests (sum of squares $=6.4$; $p<0.01)$

Table 6. Pairwise comparison between the period, lacking ICTs, and working experience.

\begin{tabular}{cccc}
\hline Lacking ICTs & Sum Square & $\boldsymbol{F}$ & $\boldsymbol{p}$-Value \\
\hline Time (Pre and post-lockdowns) & 0.87 & 1.9 & 0.28 \\
Time* Working experience (Breakpoint 20 years) & 1.96 & 2.69 & 0.11 \\
\hline
\end{tabular}

Additionally, the differences between before and after the lockdown for each variable were studied. The working experiences and the teaching at different levels did not suffer significant modifications between the two time sets $(p>0.05)$. The availability of resources (like virtual laboratories or environments, computers, or internet access) changed accordingly to each time set, improving university teachers' perception except for software (Figure 4). Additionally, the associations indicated a significant difference between preand post-lockdown in the case of VL virtual laboratories (VL) $(\rho=0.27 ; p=0.049)$, being not significant for the other assets $(p>0.05)$. 
Nothing $\quad \square$ Little $\quad \square$ A lot

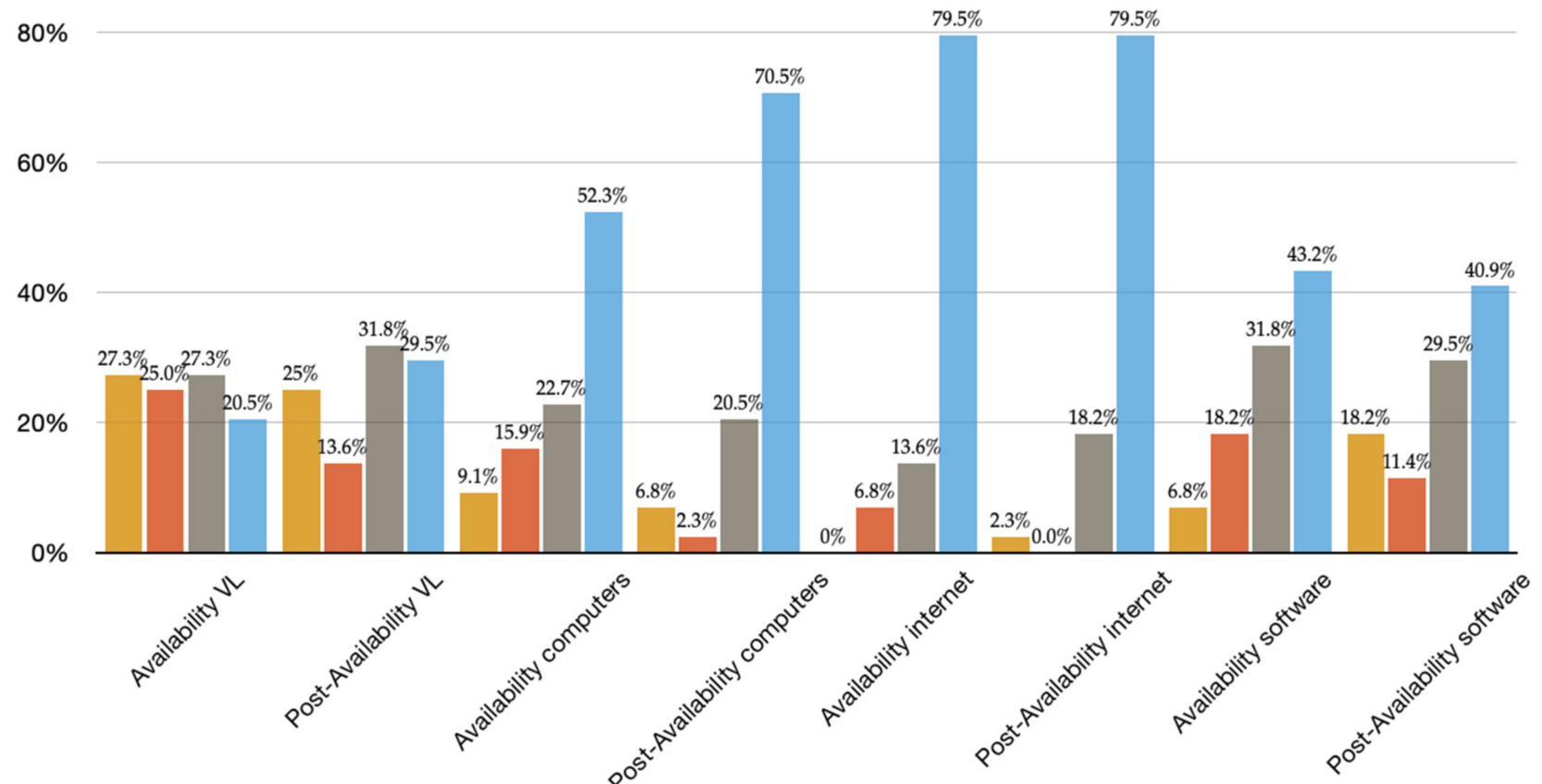

Figure 4. The opinion of university teachers about the availability of resources pre- and post-lockdown.

Moreover, the ICTs skills changed from before to after the lockdown, indicating that $4.6 \%$ of the university teachers believed they had better ICTs skills after the pandemic. Although, the change was not significant between the pre and after-the-lockdown for the ICTs skills $(p=0.9)$. ICTs skills before and after the lockdown were associated with the essentialness of ICTs $(\rho=0.33 ; p=0.03)$, frequency of using them $(\rho=0.41 ; p<0.01)$, and the importance of their role $(\rho=0.3 ; p=0.03)$. Additionally, the ICTs skills after the lockdown were linked to the frequency of using the teaching software $(\rho=0.49 ; p<0.001)$, lacking resources $(\rho=0.33 ; p=0.03)$, and lacking evidence regarding the beneficial role of ICTs in the education $(\rho=0.30 ; p=0.03)$. Based on the data, the university teachers' opinions were further studied using the multiple linear regressions having a dependent opinion about skills. The results showed that the ICTs skills before the lockdown were linked to $\left(\mathrm{R}^{2}=4.76 ; p<0.001\right)$ the essential of the ICTs $(p=0.013)$ and the frequency of using the ICTs for teaching $(p=0.009)$; and after the lockdown $\left(\mathrm{R}^{2}=6.53 ; p<0.001\right)$, it was linked to the frequency of using the ICTs for researching $(p<0.001)$, lack of resources $(p=0.017)$ and lacking software $(p=0.023)$.

\section{Discussion}

The initial results according to country showed that the university teachers' perspective differed from the country (Ecuador and Spain), which is highly important for their perspective the working experience and the different time sets. Based on these results, the first hypothesis was tested as affirmative, although it seemed that the primary factor rather than the country was the working experience. The working experience was linked to the ICTs skills, frequency of use, perception of the obstacles, or the role of ICTs in the teaching process pre- and post-lockdown. All the results have partially confirmed hypothesis 2 since the working experience is crucial for using ICTs, the perception of obstacles, and perception of the ICTs' role. However, the perception of ICTs skills was not linked to working experience before or after COVID-19, although there were differences when compared the groups.

These results showed how university teachers with less working experience and possibly younger seemed to be major agents regarding the use and integration of ICTs, 
which is crucial to achieving sustainable educational institutions. The difference between working experience could also imply that younger university teachers should receive further pedagogic training or make available models focused on ICTs inclusion to achieve sustainability in higher education. These results corroborate the findings of a great deal of the previous work that indicated how working experience, and possibility the of the workers' age [88], is a major factor in the ITCs skills [79], is also highly evaluated in this university teachers with an engineering background [65,89].

Several countries have integrated new reforms to renew the staff, gathering younger and further trained university teachers, all of this to achieve a sustainable educational institution [73]. These measures are based on creating activities related to the facilitation of decision-making and implementation of sustainability policies [90,91]. Moreover, following the present results, previous studies have demonstrated that difficulties in achieving sustainable educational institutions continue to be presented [92], and these organizations should move towards sustainable goals [93]. Nevertheless, most studies focused on the students as the most significant agents, integrating the new educational models accordingly o their age $[14,73,94]$. Despite that, Freidenfelds et al. [92] indicated that sustainable goals should focus on the stakeholders, students, researchers, and staff, being optimal to understand the teachers better.

The pre-lockdown results indicated how the university teachers' perception about accessibility to ICTs for teaching purposes was poor, improving after the first lockdowns (computers, internet, and VL) except for specific teaching software that worsens. This outcome is contrary to Tejedor et al. [78] (2020), who found that the university teachers found a lack of resources after the pandemic of COVID-19. However, this study only focused on post-lockdown. Therefore and no prior study has described it, these unexpected results could indicate how the perception of the availability of ICTs, including access, proper amount, and the correct type of technology, depends on the user's need and the specific moment [89,95]. Additionally, these results could be linked to the modifications of the teaching paradigm based on face-to-face classes to an online or virtual teaching method $[10,28]$. Another possibility is that participants' perception depends on external factors that may improve or deteriorate their opinion, explaining the changes of opinion before and after the lockdown regarding the availability of ICTs, ICTs skills, and the importance of different obstacles [96,97].

The ICTs skills were linked in the pre- and post-lockdown to whether the university teachers considered that the ICTs had an active role in the teaching-learning process. These results synced with previous studies that how the participants' opinion about the importance of ICTs is key to the correct integration of such technologies [38]. These associations might result from the need to integrate, create, and adapt to a teaching paradigm based purely on online teaching $[22,34]$. An unexpected result was that despite having to integrate an online learning process, the ICTs' frequency of use, according to university teachers, did not significantly increase after lockdowns. These results matched the finding of other authors, whose results about e-learning teaching did not increase the technologies [98]. An explanation of this could be linked to the training and ICTs skills of university teachers. In sync with this, Achard indicated how depending on the training of the teachers, online teaching did not imply more difficulties or a higher frequency of using ICTs, even though the pandemic has imposed the active role of integrating the ICTs in education to the teachers [99].

Another factor evaluated by the teachers was the essentialness of the ICTs in the teaching process. In this case, both Spain and Ecuador considered that the ICTs in education were essential before COVID-19 and after the lockdowns, showing no initial significant differences. These results could be due to the integration of ICTs daily and the importance given by different governments [37] and organizations worldwide [33,100,101]. Such relevance has been sustained during the pandemic on the efforts of the teachers and students [102]. Nevertheless, an unexpected finding was the changes of the opinions regarding the essentialness of the ICTs in the teaching process, which was related to the 
differences in time-sets and working experience. This perception drastically changed from before the pandemic and after the lockdowns, increasing older workers. Such findings could be caused by the obligatory use of ICTs for online teaching and along with the necessary understanding, skills and resources. Although these results were not previously found, this outcome seems to be in sync with previous research that indicated how the frequency of using ICT determines the importance and relevance given in [12,47].

The previous statements and the Sustainable Development Goals focused on the 4th Quality of Education [38]. It highlighted the need of improving university teachers' training or ICTs skills and renewing the institutions with younger university teachers. This approach could be more effective than providing more ICTs, which could be a pivotal task to achieve a sustainable educational system. This goal is more urgent than ever, as there has not been a previous moment in modern history with so many students suffering a disruption of their education [34]. Therefore, and based on the results, an initial model focused only on the university teachers as active agents and their use of ICTs has been proposed (Figure 5).

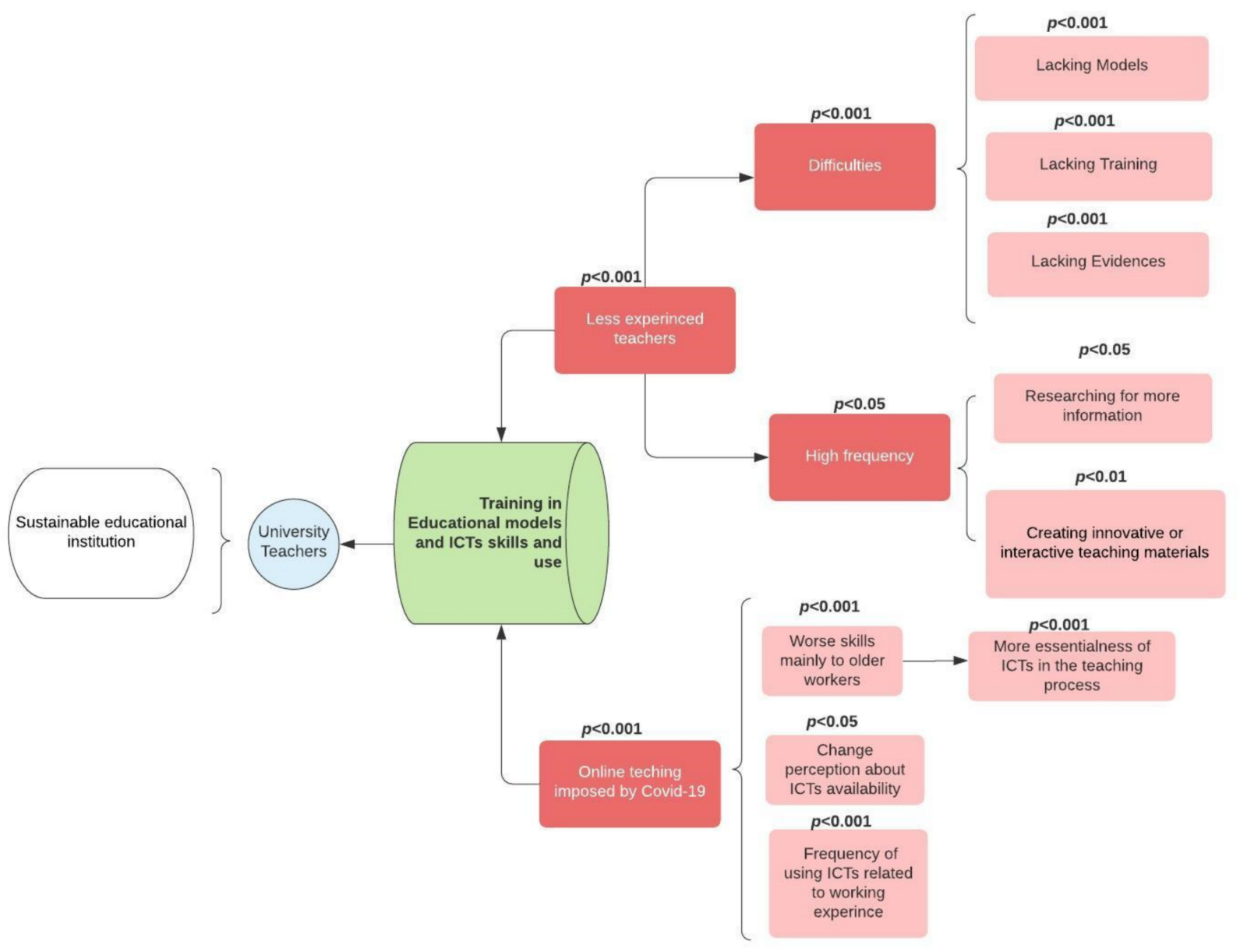

Figure 5. The model focused on university teachers for achieving a sustainable educational institution.

Figure 5 indicated that achieving sustainable educational institutions requires understanding of the roles of the university teachers and how it is imperative to provide training in regard to models that integrate the ICTs and improve the ICTs skills and their use. Additionally, the model, based on the results, highlighted the importance and difference about working experience, the relevance of the lack of models, training, and evidence as obstacles for integration ICTs. Finally, this figure indicated that the change to online teaching improved the availability of resources (VL) and the opinion of older workers regarding 
the essentialness of ICTs in the teaching process. However, it also worsened the ICTs skills in older workers. This figure shows the need to train the university teachers, but there is a need to adapt it mainly to the working experience and the population's perception.

\section{Limitations and Implications to the Field}

The current study, as any research, has some limitations. The major limitation of this study was the small sample of the university teachers participating in the study, being similar to the estimation, but it continues to be rather small. This research has obtained the data of university teachers' views using an observational method that has limited such results to the countries that have participated and the timeframe used. The survey data is based on people's opinions with a transversal cut, and it would be wise not to apply all the variables linked to other populations or in different set times.

Despite the limitations, the current study presents interesting qualitative data from a hardly studied group from HEIs, providing more evidence about how COVID-19 has modified the educational system and its sustainable capacity. Moreover, this approach was not being taken previously, as most studies focused on establishing the impact of COVID-19, the sustainability of the educational systems mainly in primary or secondary education, and did not include the perception in different moments, including personal factors such as working experience. Only one study at the intercontinental level studied the teachers' perspective, being limited to the lack of resources [77]. Despite being limited to two periods of time and two countries, the results presented in this paper could be used to illustrate the relevance of university teachers' views regarding ICTs as significant agents in creating sustainable educational systems and adapting to changes and requirements from society.

\section{Conclusions}

This paper has argued how integrating the ICTs in the education system is key to creating sustainable education institutions, being highly important for the benefit of the university teachers, their ICTs skills, and the impact of COVID-19.

The initial results according to country showed that the point of view seemed to differ for the Ecuadorian and Spanish university teachers, with the variation linked to their working experience. In this sense, the less experienced university teachers spent more time using the ICTs, identified more greatly with the problematic factors, and gave a more critical role to the ICTs independently from the country or the time set. Moreover, the results focused on comparing the pre- and post-lockdown indicated how despite having the availability of ICTs, the younger university teachers considered that there were not enough ICTs and that their skills were highly superior. Additionally, the university teachers with more experience had a change of their perception regarding the essentialness of the ICTs for the teaching process, considering them as more important after the lockdowns. Therefore, the pandemic of COVID-19 and posterior lockdowns seemed to have a major role in changing the perception of these agents in the sustainable educational system, which could be the missing piece for the complexity of full integration of ICTs.

Since the university teachers' perspective were little studied, an initial model has been presented. This model presents how the major key points seem to be linked to age and the imperative of online teaching, focusing on training university teachers in educational models and ITCs skills and how to use these. Nevertheless, there continues to be a need for further research focusing on ICTs, education, and skills, and university teachers' perception as a unit to achieve a sustainable approach about education as a pillar for both the sustainable education system and education for sustainability. Therefore, forthcoming research should focus on creating educational interventions based on providing more training, determining educators' opinions regarding lack of resources and frequency of using ICTs in HEIs. 
Author Contributions: Conceptualization, P.A.-M., M.P.M.-J., and J.A.N.-E.; Methodology, P.A.-M., M.P.M.-J. and J.A.N.-E.; Software, P.A.-M., J.A.N.-E., M.P.M.-J. and M.V.-A.; Validation, A.-J.P.-M., J.A.N.-E. and G.P.-P.; Formal Analysis, P.A.-M., J.A.N.-E., A.-J.P.-M. and M.V.-A.; Investigation, P.A.-M., J.A.N.-E. and. M.P.M.-J.; Resources, P.A.-M. and G.P.-P.; Data Curation, P.A.-M., J.A.N.E. and G.P.-P.; Writing-Original Draft Preparation, P.A.-M., J.A.N.-E., M.P.M.-J. and A.-J.P.-M.; Writing-Review and Editing, M.V.-A., M.P.M.-J. and A.-J.P.-M.; Visualization, G.P.-P. and A.-J.P.-M.; Supervision, M.P.M.-J. and P.A.-M.; Project Administration, M.P.M.-J. and M.V.-A. All authors have read and agreed to the published version of the manuscript.

Funding: This research received no external funding.

Institutional Review Board Statement: The study was conducted according to the guidelines of the Declaration of Helsinki of 1964, of the World Medical Association, and subsequent amendments, and in the 1996 Council of Europe Convention on Human Rights and Biomedicine, and the Data Protection Law 3/2018 from 5th of December. Besides, this study is framed in Occupational Safety that received Ethical Research Approval (Reference 4258).

Informed Consent Statement: Informed consent was obtained from all subjects involved in the study. Moreover, the study was conducted according to the guidelines of the Declaration of Helsinki.

Data Availability Statement: The data is available, please contact the authors.

Acknowledgments: We would like to thank the participants and institutions that help us to gather the data. The research team would like to thank you for your time and attention. You are contributing to the best knowledge and current scientific advancement.

Conflicts of Interest: The authors declare no conflict of interest.

\section{Appendix A}

Table A1. Structure and items of the survey.

\begin{tabular}{|c|c|c|}
\hline Questions & Specifications of Each Question & Answers \\
\hline Country that you are currently working: & None & $\begin{array}{l}\text { Spain } \\
\text { Ecuador } \\
\text { Other }\end{array}$ \\
\hline Level at which you teach & $\begin{array}{l}\text { Selected the one according to teaching } \\
\text { hours per week }\end{array}$ & $\begin{array}{l}\text { Undergraduate } \\
\text { Postgraduate }\end{array}$ \\
\hline $\begin{array}{l}\text { Working experience at the University } \\
\text { level: }\end{array}$ & None & $\begin{array}{l}\text { Less than one } \\
\text { From one to ten years } \\
\text { From ten to twenty } \\
\text { From twenty to thirty } \\
\text { More than thirty }\end{array}$ \\
\hline $\begin{array}{l}\text { Availability of resources (ICTs) } \\
\text { Indicate the availability of the following } \\
\text { resources for your classes of the subject: }\end{array}$ & $\begin{array}{c}0 \text { Rather not Say/Not Known } \\
1 \text { Nothing (No Availability) } \\
2 \text { Little } \\
3 \text { Enough } \\
4 \text { A lot }\end{array}$ & $\begin{array}{l}\text { Virtual laboratories or environments } \\
\text { Computers } \\
\text { Internet connection } \\
\text { Software }\end{array}$ \\
\hline \multirow{4}{*}{$\begin{array}{c}\text { ICTs skills } \\
\text { Indicate what you think is your level of } \\
\text { competence in the management of ICTs } \\
\text { or ICTs skills according to the following } \\
\text { scale: }\end{array}$} & 1 No skill & Lowest as no user \\
\hline & 2 Little & \\
\hline & 3 Enough & \\
\hline & 4 Advance or oustanding skills & $\begin{array}{l}\text { User of ICTs for design and multimedia } \\
\text { or multiplatform tool }\end{array}$ \\
\hline $\begin{array}{l}\text { Essentialness of ICTs in the teaching and } \\
\text { learning process: }\end{array}$ & $\begin{array}{l}\text { Do you think that the skills and } \\
\text { procedures used with ICTs are essential } \\
\text { for learning the subject }\end{array}$ & $\begin{array}{c}\text { Yes } \\
\text { No } \\
\text { Maybe }\end{array}$ \\
\hline
\end{tabular}


Table A1. Cont.

\begin{tabular}{|c|c|c|}
\hline Questions & Specifications of Each Question & Answers \\
\hline $\begin{array}{l}\text { Frequency of using ICTs } \\
\text { Indicate the frequency of using ICTs } \\
\text { according to working hours per week }\end{array}$ & $\begin{array}{l}1 \text { Never } \\
\begin{array}{c}2 \text { Sometimes (less than } 25 \% \text { of working } \\
\text { hours) }\end{array} \\
\text { 3 Usually } \\
\text { (50\% of working hours) } \\
4 \text { almost always } \\
\text { (more than } 75 \% \text { of working hours) } \\
5 \text { Always } \\
0 \text { Rather not say / Not known }\end{array}$ & $\begin{array}{c}\text { In general } \\
\text { As a tool to support the teahing process } \\
\text { (e.g., presentations, notes, web pages, } \\
\text { digital whiteboard...) } \\
\text { To search for information or to carry out } \\
\text { exercises to extend/reinforce the theory } \\
\text { (consultation on web pages, databases, } \\
\text { encyclopedias and specific software, } \\
\text { tutorials, self-assessment } \\
\text { questionnaires...) } \\
\text { For the realization of laboratory practices } \\
\text { and development of skills of } \\
\text { experimental work through specific } \\
\text { software (computer-assisted laboratory; } \\
\text { virtual laboratory; databases...) } \\
\text { For the elaboration of further teaching } \\
\text { materials (documentation works; } \\
\text { WebQuest; preparation of } \\
\text { presentations...) } \\
\text { As a means of communication or } \\
\text { collaborative learning (forums, } \\
\text { distribution lists, chats, wikis, blogs, } \\
\text { classroom projects...) }\end{array}$ \\
\hline Role of ICTs in the teaching process & $\begin{array}{l}\text { Do you think that the use of ICT can } \\
\text { contribute to the learning of skills and } \\
\text { procedures in teaching the subject? }\end{array}$ & $\begin{array}{l}\text { Yes } \\
\text { No } \\
\text { Maybe }\end{array}$ \\
\hline $\begin{array}{l}\text { Importance given to the lack of resources } \\
\text { Evaluate the importance for you of the } \\
\text { following obstacles to the incorporation } \\
\text { of ICT in the realization of experimental } \\
\text { work with students: }\end{array}$ & $\begin{array}{l}1 \text { Does not Constitute an Obstacle } \\
2 \text { Not very Important } \\
3 \text { Important in some cases } \\
4 \text { Quite Important } \\
5 \text { Very Important } \\
\text { 0 Rather not say / Not known }\end{array}$ & $\begin{array}{c}\text { Lack of resoruces in general (computers, } \\
\text { internet access...) } \\
\text { Lack of specific software (programs) for } \\
\text { the teaching and correct language } \\
\text { Lack of technical training in ICT } \\
\text { management } \\
\text { Lack of models or examples of curricular } \\
\text { integration in this discipline } \\
\text { Lack of time and difficulty in organizing } \\
\text { the curriculum } \\
\text { The pedagogical benefits are not clear } \\
\text { (researches, reports...) }\end{array}$ \\
\hline
\end{tabular}

\section{References}

1. Kranzberg, M. Technology and history: "Kranzberg's Laws". Bull. Sci. Technol. Soc. 1995, 15, 5-13. [CrossRef]

2. Camarillo, D.B.; Krummel, T.M.; Salisbury, J.K., Jr. Robotic technology in surgery: Past, present, and future. Am. J. Surg. 2004, 188, 2-15. [CrossRef] [PubMed]

3. Bayhan, H.G.; Karaca, E. Technological innovation in architecture and engineering education-An investigation on three generations from Turkey. Int. J. Educ. Technol. High. Educ. 2020, 17, 33. [CrossRef]

4. Anwar, M.M.; Liu, C.; Li, J. Discovering and tracking query oriented active online social groups in dynamic information network. World Wide Web 2019, 22, 1819-1854. [CrossRef]

5. Button, D.; Harrington, A.; Belan, I. E-learning \& information communication technology (ICT) in nursing education: A review of the literature. Nurse Educ. Today 2014, 34, 1311-1323. [CrossRef] [PubMed]

6. Nicol, A.A.; Owens, S.M.; Le Coze, S.S.; MacIntyre, A.; Eastwood, C. Comparison of high-technology active learning and low-technology active learning classrooms. Act. Learn. High. Educ. 2017, 19, 253-265. [CrossRef]

7. Murillo-Zamorano, L.R.; Ángel López Sánchez, J.; Bueno Muñoz, C. Gamified crowdsourcing in higher education: A theoretical framework and a case study. Think. Ski. Creat. 2020, 36, 100645. [CrossRef]

8. Fernandes, G.W.R.; Rodrigues, A.M.; Ferreira, C.A. Professional development and use of digital technologies by science teachers: A review of theoretical frameworks. Res. Sci. Educ. 2020, 50, 673-708. [CrossRef] 
9. Wang, M.; Kirschner, P.A.; Spector, J.M.; Ge, X. Computer-based learning environments for deeper learning in problem-solving contexts. Comput. Hum. Behav. 2018, 87, 403-405. [CrossRef]

10. Torres Martín, C.; Acal, C.; El Honrani, M.; Mingorance Estrada, Á.C. Impact on the virtual learning environment due to COVID-19. Sustainability 2021, 13, 582. [CrossRef]

11. Redel-Macías, M.D.; Pinzi, S.; Martínez-Jiménez, M.P.; Dorado, G.; Dorado, M.P. Virtual Laboratory on Biomass for Energy Generation. J. Clean. Prod. 2016, 112, 3842-3851. [CrossRef]

12. Potkonjak, V.; Gardner, M.; Callaghan, V.; Mattila, P.; Guetl, C.; Petrović, V.M.; Jovanović, K. Virtual laboratories for education in science, technology, and engineering: A review. Comput. Educ. 2016, 95, 309-327. [CrossRef]

13. Balasubramaniam, S.M.; Bhargava, S.; Agrawal, N.; Asif, R.; Chawngthu, L.; Sinha, P.; Kumar, S.; Sood, B. Blending virtual with conventional learning to improve student midwifery skills in India. Nurse Educ. Pr. 2018, 28, 163-167. [CrossRef]

14. Barbosa Granados, S.H.; Amariles Jaramillo, M.L. Learning styles and the use of ICT in university students within a competencybased training model. J. N. Approaches Educ. Res. 2019, 8, 1-6. [CrossRef]

15. Calabuig, F.; González Serrano, M.; Fombona, J.; García-Tascón, M. The emergence of technology in physical education: A general bibliometric analysis with a focus on virtual and augmented reality. Sustainability 2020, 12, 2728. [CrossRef]

16. Jivraj, B.A.; Schaeffer, E.; Bone, J.N.; Stunden, C.; Habib, E.; Jacob, J.; Mulpuri, K. the use of virtual reality in reducing anxiety during cast removal: A randomized controlled trial. J. Child Orthop. 2020, 14, 574-580. [CrossRef]

17. Byrne, J.; Ip, H.; Lau, K.; Li, R.; Tso, A.; Choi, C. InSPAL: A novel immersive virtual learning programme. Stud. Health Technol. Inform. 2016, 219, 129-134. [CrossRef]

18. Cózar, R.; Martínez, M.; Hernández-Bravo, J.; Hernández-Bravo, J. Conocimiento y uso de las tecnologías de la información y las comunicaciones (TIC) según el estilo de aprendizaje de los futuros maestros. Form. Univ. 2016, 9, 105-118. [CrossRef]

19. Zempoalteca, B.; Barragan Lopez, J.; Martínez, J.G.; Flores, T. Formación en TIC y competencia digital en la docencia en instituciones públicas de educación superior. Apertura 2017, 9, 80-96. (In Spanish) [CrossRef]

20. García, F.C. Design of a curricular model e-learning, using a participatory active methodology. Rev. Iberoam. Para Investig. Desarro. Educ. RIDE 2016, 7, 147-182. [CrossRef]

21. Ananiadou, K.; Claro, M. 21st century skills and competences for new millennium learners in OECD countries organisation for economic co-operation and development. OECD Educ. Work. Pap. 2009, 20, 1-34. [CrossRef]

22. Castro Sánchez, J.J.; Chirino Alemán, E. Teachers' opinion survey on the use of ICT tools to support attendance-based teaching. Comput. Educ. 2011, 56, 911-915. [CrossRef]

23. Oolbekkink Marchand, H.; van Driel, J.; Verloop, H. Perspectives on teaching and regulation of learning: A comparison of secondary and university teachers. Teach. High. Educ. 2014, 19, 799-811. [CrossRef]

24. Griffin, G.A. (Ed.) The Education of Teachers: The Ninety-Eight Yearbook of the National Society for the Study of Education; University of Chicago Press: Chicago, MI, USA, 1999.

25. Cabero, J.; Morales, J.A.; Romero, R.; Barroso, J.; Castaño, C.; Román, P.; Prendes, M.P.; Cebrián, M.; Pérez, A.; Ballestero, C.; et al formación del profesorado universitario en estrategias metodológicas para la incorporación del aprendizaje en red en el espacio europeo de educación superior (EEES). Medios Educ. 2006, 27, 11-29. (In Spanish)

26. Cabero Almenara, J. Formación del profesorado universitario en TIC. Aplicación del método Delphi para la selección de los contenidos formativos. Educ. XXI 2013, 17, 111-132. [CrossRef]

27. Espino-Díaz, L.; Fernandez-Caminero, G.; Hernandez-Lloret, C.-M.; Gonzalez-Gonzalez, H.; Alvarez-Castillo, J.-L. Analyzing the impact of COVID-19 on education professionals. toward a paradigm shift: ICT and neuroeducation as a binomial of action. Sustainability 2020, 12, 5646. [CrossRef]

28. Sofianidis, A.; Meletiou-Mavrotheris, M.; Konstantinou, P.; Stylianidou, N.; Katzis, K. Let Students Talk about Emergency Remote Teaching Experience: Secondary Students' Perceptions on Their Experience during the COVID-19 Pandemic. Educ. Sci. 2021, 11, 268. [CrossRef]

29. Dwivedi, Y.K.; Hughes, D.L.; Coombs, C.; Constantiou, I.; Duan, Y.; Edwards, J.S.; Gupta, B.; Lal, B.; Misra, S.; Prashant, P.; et al. Impact of COVID-19 pandemic on information management research and practice: Transforming education, work and life. Int. J. Inf. Manag. 2020, 55, 102211. [CrossRef]

30. Sidpra, J.; Gaier, C.; Reddy, N.; Kumar, N.; Mirsky, D.; Mankad, K. Sustaining education in the age of COVID-19: A survey of synchronous web-based platforms. Quant. Imaging Med. Surg. 2020, 10, 1422-1427. [CrossRef]

31. Barisone, M.; Bagnasco, A.; Aleo, G.; Catania, G.; Bona, M.; Gabriele Scaglia, S.; Zanini, M.; Timmins, F.; Sasso, L. The effectiveness of web-based learning in supporting the development of nursing students' practical skills during clinical placements: A qualitative study. Nurse Educ. Pr. 2019, 37, 56-61. [CrossRef]

32. COVID-19: 20 countries' higher education intra-period digital pedagogy responses. Int. Perspect. Interactions Educ. 2020, 3. [CrossRef]

33. United Nations Educational. Scientific and Cultural What Is Education for Sustainable Development? Available online: https:/ / en.unesco.org/themes/education-sustainable-development/what-is-esd (accessed on 12 March 2021).

34. Antúnez López, M.; Gomera, A.; Villamandos, F. Sustainability and curriculum: Problems and possible solutions in the spanish university context. Profesorado 2017, 21, 197-214.

35. Biasutti, M.; Concina, E.; Frate, S.; Delen, I. Teacher Professional Development: Experiences in an International Project on Intercultural Education. Sustainability 2021, 13, 4171. [CrossRef] 
36. Liesa-Orús, M.; Latorre-Cosculluela, C.; Vázquez-Toledo, S.; Sierra-Sánchez, V. The technological challenge facing higher education professors: Perceptions of ICT tools for developing 21st century skills. Sustainability 2020, 12, 5339. [CrossRef]

37. Carrión-Martínez, J.J.; Luque-de la Rosa, A.; Fernández-Cerero, J.; Montenegro-Rueda, M. Information and communications technologies (icts) in education for sustainable development: A bibliographic review. Sustainability 2020, 12, 3288. [CrossRef]

38. United Nations 4 Quality Education. Available online: https://www.un.org/sustainabledevelopment/education/ (accessed on 12 March 2021).

39. United Nations Open Working Group Proposal for Sustainable Development Goals. Available online: https://sustainabledevel opment.un.org/focussdgs.html (accessed on 12 April 2021).

40. Segerberg, A.; Bennett, W.L. Social media and the organization of collective action: Using twitter to explore the ecologies of two climate change protests. Commun. Rev. 2011, 14, 197-215. [CrossRef]

41. Fernández-Portillo, A.; Almodóvar-González, M.; Hernández-Mogollón, R. Impact of ICT development on economic growth. A study of OECD European Union countries. Technol. Soc. 2020, 63, 101420. [CrossRef]

42. Vehviläinen, M.; Brunila, K. cartography of gender equality projects in ICT: Liberal equality from the perspective of situated equality. Commun. Soc. 2007, 10, 384-403. [CrossRef]

43. Pauw, J.B.; Gericke, N.; Olsson, D.; Berglund, T. The effectiveness of education for sustainable development. Sustainability 2015, 7, 15693-15717. [CrossRef]

44. Vaterlaus, J.M.; Patten, E.V.; Roche, C.; Young, J.A. \#Gettinghealthy: The perceived influence of social media on young adult health behaviors. Comput. Hum. Behav. 2015, 45, 151-157. [CrossRef]

45. Dev, H.; Ali, M.E.; Hashem, T. User interaction based community detection in online social networks. In Database Systems for Advanced Applications, Proceedings of the International Conference on Database Systems for Advanced Applications, Bali, Indonesia, 21-24 April 2014; Bhowmick, S.S., Dyreson, C.E., Jensen, C.S., Lee, M.L., Muliantara, A., Thalheim, B., Eds.; Springer: Cham, Switzerland, 2014; pp. 296-310.

46. Greenhow, C.; Lewin, C. Social media and education: Reconceptualizing the boundaries of formal and informal learning. Learn. Media Technol. 2016, 41, 6-30. [CrossRef]

47. Daniela, L.; Visvizi, A.; Gutiérrez-Braojos, C.; Lytras, M. Sustainable higher education and technology-enhanced learning (TEL). Sustainability 2018, 10, 3883. [CrossRef]

48. Álvarez-Arregui, E.; Rodríguez-Martín, A.; Madrigal-Maldonado, R.; Grossi-Sampedro, B.-Á.; Arreguit, X. Ecosistemas de formación y competencia mediática: Valoración internacional sobre su implementación en la educación superior-ecosystems of media training and competence: International assessment of its implementation in higher education. Rev. Comun. 2017, 25, 105-114. (In Spanish) [CrossRef]

49. Secretaría de Educaión Superior. Situación de La Educación Superior; Secretaría de Educaión Superior, Ciencia, Tecnología e Innovación, Presencia República de Ecuador: Quito, Ecuador, 2017; p. 24. (In Spanish)

50. Alsulami, S.A.; Sherwood, G. The experience of culturally diverse faculty in academic environments: A multi-country scoping review. Nurse Educ. Pract. 2020, 44, 102777. [CrossRef]

51. Pfahl, S. Institutional Sustainability. Int. J. Sustain. Dev. 2005, 8, 80. [CrossRef]

52. Ravindran, G.; Nagendran, R. Study on Need for Sustainable Development in Educational Institutions, an Ecological PerspectiveA Case Study of College of Engineering-Guindy, Chennai. J. Urban Environ. Eng. 2010, 4. [CrossRef]

53. Ben-Eliyahu, A. Sustainable learning in education. Sustainability 2021, 13, 4250. [CrossRef]

54. da Rocha Seixas, L.; Gomes, A.S.; de Melo Filho, I.J. Effectiveness of gamification in the engagement of students. Comput. Hum. Behav. 2016, 58, 48-63. [CrossRef]

55. González-Zamar, M.-D.; Abad-Segura, E.; López-Meneses, E.; Gómez-Galán, J. Managing ICT for sustainable education: Research analysis in the context of higher education. Sustainability 2020, 12, 8254. [CrossRef]

56. UNESCO Global Education Monitoring (GEM) Report 2020. Available online: https:/ / en.unesco.org/news/global-educationmonitoring-gem-report-2020 (accessed on 20 May 2021).

57. United Nations. UNESCO Education in the Time of COVID-19; United Nations: Santiago, Chile, 2020; p. 20.

58. IIPE UNESCO Sistematización de Respuesta de Los Sistematicas Educativas de América Latina a La Crisis de La COVID-19. Available online: https:/ / siteal.iiep.unesco.org/respuestas_educativas_covid_19 (accessed on 20 May 2021).

59. Lorente, L.M.L.; Arrabal, A.A.; Pulido-Montes, C. The right to education and ICT during COVID-19: An international perspective. Sustainability 2020, 12, 9091. [CrossRef]

60. Espinoza Cordero, C.X.; Socorro Castro, A.R.; Soler McCook, J.M.; Hernández Toazo, H.; Guerra Maldonado, C.P. Sistema Estructurado de Gestión Del Aprendizaje Virtual de La Universidad Metropolitana Del Ecuador. Rev. Univ. Soc. 2020, $12,404-414$. (In Spanish)

61. European Univeristy Associaton. European Higher Education in the Covid-19 Crisis; European University Association: Geneva, Switzerland, 2020; p. 10.

62. Zhou, L.; Li, F.; Wu, S.; Zhou, M. "School's Out, But Class's On", The largest online education in the world today: Taking China's practical exploration during the COVID-19 epidemic prevention and control as an example. Best Evid. Chin. Edu. 2020, 4, 501-519. [CrossRef]

63. Fundación ECOTEC. Educación y Covid-19: Escuela en Casa y Desigualdad, Educación y Covid-19; Fundación ECOTEC: Madrid, Spain, 2020; p. 20. (In Spanish) 
64. Aznar Sala, F.J. La educación secundaria en españa en medio de la crisis del COVID-19. RISE 2020, 53. [CrossRef]

65. Revilla-Cuesta, V.; Skaf, M.; Varona, J.M.; Ortega-López, V. The outbreak of the COVID-19 pandemic and its social impact on education: Were engineering teachers ready to teach online? Int. J. Environ. Res. Public Health 2021, 18, 2127. [CrossRef]

66. Díez-Gutiérrez, E.-J.; Gajardo Espinoza, K. Education Online in Lockdown: Limits and Possibilities. The Vision of Families in Spain. Equal. Divers. Incl. 2021. [CrossRef]

67. Batez, M. ICT skills of university students from the faculty of sport and physical education during the COVID-19 pandemic. Sustainability 2021, 13, 1711. [CrossRef]

68. Ozamiz-Etxebarria, N.; Santamaría, M.D.; Mondragon, N.I. Estado emocional del profesorado de colegios y universidades en el norte de españa ante la COVID-19(*). Rev. Esp. Salud. Pública 2021, 95, e1-e8. (In Spanish)

69. Feyen, J. Shall COVID-19 Accelerate the transfer of passive learning to active education? Maskana 2020, 11, 1-4. [CrossRef]

70. Ponce Jarrín, J. Informe Nacional: Ecuador, Educacion Superior en Iberoamerica Informe 2016. Universia. Available online: https:/ / cinda.cl/wp-content/uploads/2019/01/educacion-superior-en-iberoamerica-informe-2016-informe-nacional-e cuador.pdf (accessed on 3 April 2021). (In Spanish).

71. Hernáez, Á.; Zomeño, M.D.; Dégano, I.R.; Pérez-Fernández, S.; Goday, A.; Vila, J.; Civeira, F.; Moure, R.; Marrugat, J. Exceso de peso en España: Situación actual, proyecciones para 2030 y sobrecoste directo estimado para el Sistema Nacional de Salud. Rev. Española Cardiol. 2019, 72, 916-924. [CrossRef]

72. Asanov, I.; Flores, F.; McKenzie, D.; Mensmann, M.; Schulte, M. Remote-learning, time-use, and mental health of ecuadorian high-school students during the COVID-19 quarantine. World Dev. 2021, 138, 105225. [CrossRef] [PubMed]

73. Alvarez-Risco, A.; Del-Aguila-Arcentales, S.; Rosen, M.A.; García-Ibarra, V.; Maycotte-Felkel, S.; Martínez-Toro, G.M. Expectations and interests of university students in COVID-19 Times About Sustainable Development Goals: Evidence from Colombia, Ecuador, Mexico, and Peru. Sustainability 2021, 13, 3306. [CrossRef]

74. Garcia Laborda, J.; Concha Diaz, V.; Jechimer Ramírez, E. Foreign language pre-service teachers' attitudes towards integrated technology. Int. J. Emerg. Technol. Learn. 2020, 15, 85. [CrossRef]

75. Montenegro, S.; Raya, E.; Navaridas, F. Percepciones docentes sobre los efectos de la brecha digital en la educación básica durante el Covid-19. Rev. Int. Educ. Justicia Soc. 2020, 9, 317-333. (In Spanish) [CrossRef]

76. Said-Hung, E.; Garzón-Clemente, R.; Marcano, B. Ibero-american higher education institutions facing COVID-19. J. Hum. Behav. Soc. Environ. 2021, 31, 497-511. [CrossRef]

77. Tejedor, S.; Cervi, L.; Pérez-Escoda, A.; Jumbo, F.T. Digital literacy and higher education during COVID-19 lockdown: Spain, Italy, and Ecuador. Publications 2020, 8, 48. [CrossRef]

78. Tejedor, S.; Cervi, L.; Tusa, F.; Parola, A. Educación en tiempos de pandemia: Reflexiones de alumnos y profesores sobre la enseñanza virtual universitaria en España, Italia y Ecuador. Rev. Lat. 2020, 1-21. [CrossRef]

79. Alazam, A.-O.; Bakar, A.; Hamzah, R.; Asmiran, S. Teachers' ICT skills and ICT integration in the classroom: The case of vocational and technical teachers in Malaysia. Creat. Educ. 2012, 3, 70-76. [CrossRef]

80. Sánchez Ruiz, L.M.; Moll-López, S.; Moraño-Fernández, J.A.; Llobregat-Gómez, N. B-learning and technology: Enablers for university education resilience. an experience case under COVID-19 in Spain. Sustainability 2021, 13, 3532. [CrossRef]

81. Thomas, S. Taking teachers out of the equation: Constructions of teachers in education policy documents over a ten-year period. Aust. Educ. Res. 2005, 32, 45-62. [CrossRef]

82. Revista de Promción de la Inestigación Ranking QS, Mejores Universidades en Ingeniería y Tecnología. Available online: https: / / www.revistanuve.com/ranking-qs-mejores-universidades-en-ingenieria-y-tecnologia/ (accessed on 15 October 2020). (In Spanish).

83. Christie, M.; Jaun, A.; Jonsson, L.-E. Evaluating the use of ICT in engineering education. Eur. J. Eng. Educ. 2002, 27, 13-20. [CrossRef]

84. Direito, I.; Pereira, A.; De Oliveira Duarte, A.M. The development of skills in the ICT sector: Analysis of engineering students' perceptions about transversal skills. Int. J. Eng. Educ. 2014, 30, 1556-1561.

85. Balladares-Burgos, J.A. Diseño pedagógico de la educación digital para la formación del profesorado | Instructional design of digital education for teacher training. Rev. Latinoam. Tecnol. Educ. 2018, 17, 20. (In Spanish) [CrossRef]

86. Delegación Central de Estudiantes de la Universidad Computense de Madrid. Análisis de los Resultados de la Encuesta Realizada por la Delegación Central de Estudiantes; Universidad Computense: Madrid, Spain, 2020.

87. Roberts, L.; Allen, P. Exploring ethical issues associated with using online surveys in educational research. Educ. Res. Eval. 2015, 21. [CrossRef]

88. Karamti, C. Measuring the impact of ICTs on academic performance: Evidence from higher education in Tunisia. J. Res. Technol. Educ. 2016, 48, 322-337. [CrossRef]

89. Arteaga, M.; Tomczyk, Ł.; Oyelere, S.; Barros, G.J. ICT and Education in the Perspective of Experts from Business, Government, Academia and NGOs in Europe, Latin America and Caribbean; Universidad del Azuay: Cuenca, Equador, 2020; ISBN 978-9942-82-261-1.

90. Coates, H.; Dobson, I.; Edwards, D.; Friedman, T.; Goedegebuure, L.; Meek, L. The Attractiveness of the Australian Academic Profession: A Comparative Analysis; LH Martin Institute, University of Melbourne, Australian Council for Educational Research, Educational Policy Institute: Melbourne, Australia, 2009. 
91. Villamandos de la Torre, F.; Gomera Martínez, A.; Antúnez López, M. Conciencia ambiental y sostenibilización curricular, dos herramientas en el camino hacia la sostenibilidad de la Universidad de Córdoba. Rev. Educ. Ambient. Sostenibilidad 2019, 1, 1-19. (In Spanish) [CrossRef]

92. Granados Sanchez, J.; Wals, A.; Ferrer-Balas, D.; Waas, T.; Imaz, M.; Nortier, S.; Svanström, M.; Land, H.; Arriaga, G. Sustainability in higher education: Moving from understanding to action, breaking barriers for transformation. In Higher Education in the World; Palgrave MacMilan: London, UK, 2011; Volume 4, pp. 193-207, ISBN 978-0-230-53555-8.

93. Freidenfelds, D.; Kalnins, S.N.; Gusca, J. What does environmentally sustainable higher education institution mean? Energy Procedia 2018, 147, 42-47. [CrossRef]

94. Krejci, S.E.; Ramroop-Butts, S.; Torres, H.N.; Isokpehi, R.D. Visual literacy intervention for improving undergraduate student critical thinking of global sustainability issues. Sustainability 2020, 12, 209. [CrossRef]

95. Almerich, G.; Suárez-Rodríguez, J.; Díaz-García, I.; Orellana, N. The influence of using ICT in high-skills competences and ICT competences. A structural model. Educ. Inf. Technol. 2021. [CrossRef]

96. Aljabri, D.; Vaughn, A.; Austin, M.; White, L.; Li, Z.; Naessens, J.; Spaulding, A. An Investigation of Healthcare Worker Perception of Their Workplace Safety and Incidence of Injury. Workplace Health Saf. 2020, 68, 214-225. [CrossRef]

97. Alston, W.P. Chapter 4. Empirical arguments for the reliability of SP. In The Reliability of Sense Perception; Cornell University Press: Ithaca, NJ, USA, 1996; pp. 60-119.

98. Flores Alarcia, Ó.; del Arco Bravo, I. The Impact of ICTs on lecturer and student interaction in university education processes. RUSC. Univ. Knowl. Soc. J. 2012, 9, 31. [CrossRef]

99. Achard, I. ¿Nuevo rol o nueva identidad docente en la era digital? In Las Tecnologías en (y para) la Educación; García, J.M., García Cabeza, S., Eds.; FLACSO: Montevideo, Uruguay, 2020; Volume 3, pp. 45-46, ISBN 978-9915-9329-0-3. (In Spanish)

100. Pandolfini, V. Exploring the impact of ICTs in education: Controversies and challenges. Ital. J. Sociol. Educ. 2016, 8, 28-53. [CrossRef]

101. Gochfeld, M. Occupational medicine practice in the United States since the industrial revolution. J. Occup. Env. Med. 2005, 47, 115-131. (In Spanish) [CrossRef]

102. Lugo, M.T.; Loiácono, F. Planificar la educación en la pospandemia: De la educación remota de emergencia a los modelos híbridos. In Las Tecnologías en (y para) la Educación; García, J.M., García Cabeza, S., Eds.; FLACSO: Montevideo, Uruguay, 2020; Volume 3, pp. 15-43, ISBN 978-9915-9329-0-3. (In Spanish) 